\title{
Antioxidant activity and physiological performance of popcorn seed after saline stress and analysis of seedling images
}

\section{Atividade antioxidante e desempenho fisiológico de semente de milho pipoca após o estresse salino e análise de imagens de plântulas}

\author{
Hugo Cesar Rodrigues Moreira Catão ${ }^{*(\mathbb{D}}$, Franciele Caixeta ${ }^{2}$ (D) Amanda Moreira Lopes ${ }^{3}$ (D), \\ Flavia Andrea Nery-Silva' (iD), Adílio de Sá Júnior ${ }^{1}$ (i)
}

\author{
'Universidade Federal de Uberlândia/UFU, Instituto de Ciências Agrárias, Uberlândia, MG, Brasil \\ ${ }^{2}$ General Mills Brasil Alimentos Ltda., São Bernardo do Campo, SP, Brasil \\ ${ }^{3}$ Escola Mario Quintana, Pelotas, RS, Brasil \\ *Corresponding author: hugo.catao@ufu.br \\ Received in March 5, 2020 and approved in July 17, 2020
}

\begin{abstract}
Salinity influences all germination stages and may adversely affect seedling establishment in the field. The objective of this research was to determine the relationship between the antioxidant activity and the physiological performance of seeds and to verify the efficacy of the imaging analysis of popcorn seedlings after seed exposure to saline stress. A completely randomized design was used that consisted of four replicates in a factorial scheme. This scheme comprised three popcorn hybrids (P618, AP6002, and AP8203) and five saline potential levels $(0.0 ;-0.1 ;-0.3 ;-0.6$, and $-0.9 \mathrm{MPa})$ that were obtained from $\mathrm{KCl}$ solutions of different concentrations. First count germination, germination and seedling vigor classification (strong normal seedlings), and dry mass of seedlings were evaluated to determine the physiological quality of the seed. The images of seedlings were used to evaluate the coleoptile and root lengths, indices of vigor, uniformity, and growth using the Groundeye ${ }^{\circledR}$ software. The activities of the antioxidant enzymes superoxide dismutase (SOD), ascorbate peroxidase (APX), and catalase (CAT) were also determined. Saline stress compromises the physiological quality and antioxidant activity of seeds and the performance of popcorn seedlings. Computerized image analysis using Groundeye ${ }^{\circledR}$ was efficient in evaluating the popcorn seedlings after being subjected to salt stress. Hybrids AP6002 and AP8203 were more tolerant to salt stress than hybrid P618.
\end{abstract}

Index terms: Zea mays var. everta; physiological quality; seed vigor; image processing; salinity.

\section{RESUMO}

A salinidade tem influência em todas as etapas da germinação e pode afetar consideravelmente o estabelecimento de plântulas em campo. Os objetivos desta pesquisa foram determinar a atividade antioxidante, o desempenho fisiológico das sementes e analisar imagens de plântulas de milho pipoca após exposição das sementes a estresse salino. Utilizou-se delineamento experimental inteiramente casualizado com quatro repetições, em arranjo fatorial com três híbridos de milho pipoca (P618, AP6002, AP8203) e cinco potenciais salinos $(0,0 ;-0,1 ;-0,3 ;-0,6$ e - - , $9 \mathrm{MPa})$. A qualidade fisiológica das sementes foi avaliada por meio da primeira contagem de germinação, germinação, classificação do vigor de plântulas (plântulas normais fortes) e massa seca das plântulas. Avaliaramse, também os comprimentos do coleóptilo e raiz, índices de vigor , uniformidade e crescimento de plântulas, mediante análise computadorizada de imagens, com utilização do software Groundeye ${ }^{\circledR}$. A atividade de enzimas antioxidantes superóxido dismutase (SOD), ascorbato peroxidase (APX) e catalase (CAT) também foi determinada. O estresse salino compromete a qualidade fisiológica e a atividade antioxidante de sementes e o desempenho de plântulas de milho pipoca. A análise computadorizada de imagens usando Groundeye $^{\circledR}$ foi eficiente na avaliação de plântulas de milho pipoca após as sementes serem submetidas ao estresse salino. Os híbridos AP6002 e AP8203 são mais tolerantes ao estresse salino.

Termos para indexação: Zea mays var. everta; qualidade fisiológica; vigor de sementes; processamento de imagens; salinidade. 


\section{INTRODUCTION}

The availability of popcorn (Zea mays L. everta) hybrids in Brazil is scarce. This necessitates the importation of significant volumes of seeds (Catão; Caixeta, 2017). However, the production is increasing, and it represents an advantageous income source due to the benefit of the product (Rocha et al., 2018; Kavan et al., 2019). This increase is a consequence, at least in part, of the selection, development, and adaptation of imported cultivars to the climatic conditions in the country (Catão; Caixeta, 2017). Nevertheless, to increase the probability of success, the use of popcorn seeds with high physiological potential is essential to establish commercial crops.

Salinity is important abiotic stress that affects production in several regions. It is aggravated by inadequate agricultural practices, especially those associated with irrigated agriculture (Sudério et al., 2011). Popcorn is grown in the second harvest and often with the use of irrigation. Moterle et al. (2006) reported that salinity resulted in problems in the physiological performance of seeds of national popcorn cultivars. However, this type of evaluation was not carried out on imported cultivars that currently predominated the Brazilian market.

Negative values of osmotic potential delay and reduce the speed and percentage of germination after impairing the sequence of germination events during water absorption (Pereira; Catão; Caixeta, 2020). When water is removed below the limit tolerated by the cell, due to drought or a saline environment, the concentration of solutes may increase. This modifies the $\mathrm{pH}$ of the intercellular solution and accelerates the degenerative reactions resulting in the denaturation of proteins, loss of membrane integrity, and an increase in the rates of abnormal and damaged plants (Pereira et al., 2014).

Studies that simulate water and saline stress in the soil have been performed under laboratory conditions using aqueous solutions of different osmotic potentials to moisten the germination substrates (Pereira; Catão; Caixeta, 2020). Such stress factors usually reduce the speed and percentage of seed germination. Reduction of water potential associated with the toxic effect of saline soils initially interferes in the water absorption process. This may influence seed germination and vigor, and consequently, the normal development of the plant (Marcos-Filho, 2016).

Exposure to excess salts triggers several important biochemical and physiological processes causing the accumulation of reactive oxygen species (ROS) such as superoxide $\left(\mathrm{O}_{2}^{-}\right)$and hydroxyl radicals $\left(\mathrm{OH}^{-}\right)$, hydrogen peroxide $\left(\mathrm{H}_{2} \mathrm{O}_{2}\right)$, and singlet oxygen $\left({ }^{1} \mathrm{O}_{2}\right)$; this also affects the defense system of the antioxidant enzymes (Joseph; Jini, 2011). The excessive production of such functional groups of radicals may result in the oxidation of cellular membranes and hence a reduction in plant growth and development (Forman; Maiorino; Ursini, 2010). Antioxidant enzymes such as superoxide dismutase (SOD), catalase (CAT), ascorbate peroxidase (APX), and peroxidase (POX) constitute the primary defense against free radicals generated under stress conditions (El-Shabrawi et al., 2010; Deuner et al., 2011).

Excess salt may reduce the rate of germination and seedling growth. This may cause difficulties in performing the manual measurement of seedling length under normal and stress conditions. Moreover, this is a time-consuming task and often subject to variations between seed analysts (Pereira; Catão; Caixeta, 2020). An alternative option of reducing the time taken to complete the manual evaluation, as well as the subjectivity of the test can be the automation of the procedure. This can be achieved by evaluating the digitalized seedling images, which allows for differentiating the seed lots according to their vigor level (Trujillo; Gomes-Junior; Cicero, 2019). The analysis of digitalized images results in a reliable evaluation of seedlings obtained from germinated seeds. It also enables the differentiation of seed lots in a relatively faster and precise analytical manner (Pinto et al., 2015).

A minimum value of saline potential is tolerated by each species, below which germination does not occur. Consequently, a great variety of responses is observed from the highly sensitive to the significantly salt-tolerant species (Bewley; Black, 1994). Thus, the objective of this research was to determine the relationship between the antioxidant activity and the physiological performance of seeds and to verify the efficacy of the imaging analysis of popcorn seedlings after seed exposure to saline stress.

\section{MATERIAL AND METHODS}

The research was performed at the Seed Laboratory of the Institute of Agrarian Sciences at the Federal University of Lavras (UFLA) in Lavras/MG, Brazil. Hybrid popcorn seeds from the company Ag Alumni Seed, produced in Indiana, USA, were used. The initial quality of the seeds was evaluated by employing the water content tests (\%), first germination count $(\%)$, germination (\%), and field emergence. The seed water content was determined by the oven method at $105^{\circ} \mathrm{C}$ for $24 \mathrm{~h}$ (Brasil, 2009). The germination test was performed according to Brasil (2009). The sowing was carried out in the field with 
four sub-samples of 50 seeds distributed at a depth of 3.0 $\mathrm{cm}$ with $0.5 \mathrm{~cm}$ spacing in $1.0 \mathrm{~m}$ long furrows. The soil was moistened to $60 \%$ of the water-holding capacity. On the tenth day after the stand was stabilized, the number of emerged seedlings was counted, and the results were expressed as a percentage.

The experiment was performed in a completely randomized design in a factorial $3 \times 5$ scheme with three popcorn hybrids (P618, AP6002, and AP8203) and five saline concentrations of potassium chloride $(\mathrm{KCl})$ solution, i.e., 0.0 (control, using only deionized water); $-0.1 ;-0.3$; -0.6 ; and -0.9 MPa with four replicates in each. The saline solutions of $\mathrm{KCl}$ were prepared with deionized water, and the required concentration of salt was obtained from the Van't Hoff equation according to Salisbury and Ross (1991); \%os $=$-RTC, where: $\Psi$ os $=$ osmotic potential (atm); $\mathrm{R}=$ general constant of perfect gases $\left(8.32 \mathrm{~J} \mathrm{~mol}^{-1}\right.$ $\left.\mathrm{K}^{-1}\right) ; \mathrm{T}=$ temperature $\left(\mathrm{K}=273+\mathrm{T}^{\circ} \mathrm{C}\right) ; \mathrm{C}=$ concentration $\left.(\mathrm{mol} \mathrm{L})^{-1}\right)$.

The germination test was performed with four replicates of 50 seeds each that were sown in a germitest paper moistened with deionized water in a proportion of $2.5 \mathrm{~mL} \mathrm{~g}^{-1}$ of dry paper. Papers were moistened with the previously mentioned $\mathrm{KCl}$ concentrations or water (control) as described. They were rolled and kept in plastic bags during the test to avoid water evaporation and to ensure that the desired osmotic potentials were maintained during the whole period of germination. Seeds were then germinated at a constant temperature of $25^{\circ} \mathrm{C}$ in a biological oxygen demand (B.O.D.) chamber with a photoperiod of $12 \mathrm{~h}$. The evaluations were performed after four and seven days of sowing the seeds.

On the fourth day after sowing, the paper rolls were substituted with new rolls moistened using the initially planned $\mathrm{KCl}$ solutions. This procedure ensured that the desired osmotic potential values were conserved. The germination counts were performed after four and seven days of sowing for determining the percentage of normal seedlings (Brasil, 2009). The results were expressed in percentage. On the seventh day, seedling vigor (classification of normal strong seedling was defined as that seedling that had at least $2 \mathrm{~cm}$ length of its aerial portion and two or more secondary roots with at least 6 cm length) was also evaluated (Nakagawa, 1999; Abreu et al., 2014).

The dry mass was determined for normal seedlings from the germination test. These were conditioned in paper bags and dried in a forced-air oven at $65^{\circ} \mathrm{C}$ for $48 \mathrm{~h}$. After this period, the samples were removed from the oven and allowed to cool in a desiccator. The samples were then weighed to determine the dry mass of the normal seedlings. The results were expressed in $\mathrm{mg} / \mathrm{seedling}$.

Next, the images were analyzed using the Groundeye ${ }^{\circledR}$ software by using the seedlings obtained from the germitest paper moistened with the same saline potentials as previously described. Four replicates of 20 seeds each were distributed in two longitudinal rows with 10 seeds in each row; they were uniformly separated to enable the free development of seedlings. Seedling images were captured four days after sowing, and the analysis was performed with automatic calibration parameters using the $R G B$ color thresholding model without subsequent correction for errors in the identification of plant parts by the software. Seedling images were evaluated by the mean length of the coleoptiles and primary roots and by the automatic vigor index, uniformity, and growth provided by the Groundeye ${ }^{\circledR}$ software according to the criteria recommended by (Pinto et al., 2015).

The activity of the following antioxidant enzymes was evaluated: superoxide dismutase (SOD - IUBMB: EC 1.15.1.1), ascorbate peroxidase (APX - IUBMB: EC 1.11.1.11), and catalase (CAT - IUBMB: EC 1.11.1.6) in order to verify the effect of osmotic potentials on the antioxidant metabolism of popcorn seeds. To access this information, $200 \mathrm{mg}$ of tissues were collected after preserving the seeds for $72 \mathrm{~h}$ in the same conditions of the germination test. Tissues were macerated with $50 \%$ insoluble polyvinylpylorrolidone (PVP) with precautions to avoid oxidation of the material. They were then homogenized in $1.5 \mathrm{~mL}$ of the extract buffer comprising $100 \mathrm{mM}(\mathrm{pH}$ 7.0) potassium phosphate, 0.1 $\mathrm{mM}$ EDTA, and $10 \mathrm{mM}$ ascorbic acid. The homogenate was centrifuged at $13,000 \mathrm{xg}$ for $10 \mathrm{~min}$ at $4{ }^{\circ} \mathrm{C}$ and the supernatant was collected. Enzyme activity was calculated from the spectrophotometric absorbance values at specific wavelengths.

Evaluation of the SOD activity was based on the ability of this enzyme to inhibit the photoreduction of nitro blue tetrazolium (NBT) (Giannopolitis; Ries, 1977) in a solution containing $100 \mathrm{mM}$ potassium phosphate $(\mathrm{pH}$ 7.8), $14 \mathrm{mM}$ methionine, $0.1 \mu \mathrm{M}$ EDTA, $75 \mu \mathrm{M}$ NBT, and $2 \mu \mathrm{M}$ riboflavin. Readings were recorded at $560 \mathrm{~nm}$. One SOD unit corresponds to the enzyme quantity capable of inhibiting $50 \%$ of the NBT photoreduction under the assay conditions.

The activity of APX was evaluated according to Nakano and Asada (1981) by estimating the oxidation rate of ascorbate at $290 \mathrm{~nm}$. The reaction solution incubated at $28{ }^{\circ} \mathrm{C}$ comprised of $100 \mathrm{mM}$ potassium phosphate buffer (pH 7.0), $0.5 \mathrm{mM}$ ascorbic acid, and $0.1 \mathrm{mM} \mathrm{H}_{2} \mathrm{O}_{2}$. The 
activity of CAT was determined according to Azevedo et al. (1998) with some modifications. The decrease in the absorbance at $240 \mathrm{~nm}$ for $2 \mathrm{~min}$ was estimated in a reaction solution containing $100 \mathrm{mM}$ potassium phosphate ( $\mathrm{pH} 7.0)$ and $12.5 \mathrm{mM} \mathrm{H}_{2} \mathrm{O}_{2}$.

Data were submitted to variance analysis and means were compared by the Scott-Knott test $(P \leq 0.05)$. When a significant effect was detected, this was tested by polynomial regression models using the statistical software Sisvar (Ferreira, 2011). The models were chosen based on statistical significance ( $F$ test) in the fitness of the coefficient of determination $\left(\mathrm{R}^{2}\right)$. The data from the analysis of images and antioxidant activity were transformed to $\mathrm{y}=\left((\mathrm{x}+1)^{\wedge} 0.5\right)$.

\section{RESULTS AND DISCUSSION}

Popcorn seeds displayed good physiological quality according to the first count (FCG), germination $(\mathrm{G})$, and emergence (E) tests shown in Table 1. The seeds of the evaluated hybrids met the minimum germination standard ( $85 \%)$ established by the legislation for commercialization (Brasil, 2013).

Table 1: Initial physiological quality of popcorn hybrid seeds.

\begin{tabular}{cccc}
\hline Hybrid & FCG (\%) & G (\%) & E (\%) \\
\hline P618 & 97 & 98 & 95 \\
AP6002 & 98 & 98 & 97 \\
AP8203 & 98 & 99 & 97 \\
\hline
\end{tabular}

The initial high quality of hybrids was important to verify the influence of saline stress on germination and seedling development. Another relevant question to consider was the homogeneity of the initial content of water in the seeds. It is essential to prevent the water content from being a source of variation in the results. The water content of seeds was $12.9 \%, 12.5 \%$, and $12.7 \%$ for hybrids P618, AP6002, and AP8203, respectively. According to Marcos-Filho (2016), a difference of 1 to $2 \%$ in the water content between samples does not compromise the results and the test can be performed.

The first count germination data allowed the verification of the statistical differences between the popcorn hybrids. Hybrid P618 displayed less vigor than hybrids AP8203 and AP6002 starting from the saline potential of $-0.1 \mathrm{MPa}$ (Figure 1A).
At an osmotic potential of $-0.3 \mathrm{MPa}$, it was observed that the germination of hybrids AP8203 and AP6002 was superior to that of P618 (Figure 1B). Therefore, by altering the osmotic potential of the substrate with different saline solutions, the seeds were able to absorb enough water to activate the metabolism, and consequently, the growth of the embryo. This enabled the exposure of the structures that conditioned a normal seedling (Silva; Grzybowski; Panobianco, 2016).

At an osmotic potential of $-0.6 \mathrm{MPa}$, the development of normal seedlings was observed. At a potential of -0.9 $\mathrm{MPa}$, no normal seedling developed (Figure 1B). The saline potential of $-0.9 \mathrm{MPa}$ negatively affected the seed viability and vigor and, therefore, the development of popcorn seedlings of the hybrids. An example of this is shown in Figure 2 for hybrid AP6002. Moterle et al. (2006) reported that the percentage of normal seedlings of popcorn decreased with the reduction of osmotic potential; germination was completely inhibited when seeds were exposed to the lowest potential (-0.9 MPa).

The evaluation of the percentage of strong normal seedlings (Figure 2C) indicated an accentuated reduction in seed vigor as the saline stress increased. In the control treatment $(0.0 \mathrm{MPa})$, it was not possible to differentiate the hybrid seeds under study with respect to their vigor level. This resulted in registering a high percentage of strong normal seedlings. At a saline potential of -0.3 and -0.6 $\mathrm{MPa}$, tolerance to stress was observed in hybrids AP8203 and AP6002. At a potential of $-0.6 \mathrm{MPa}$, seed vigor was significantly reduced as reflected by the low percentage of strong normal seedlings. At a saline potential of $-0.9 \mathrm{MPa}$, not a single strong normal seedling was identified (Figure 1C). These results are similar to those from Moterle et al. (2006), wherein salt-induced stress reduced the percentage of strong normal seedlings in almost all evaluated corn hybrids.

The dry mass of seedlings of popcorn hybrids decreased with the reduction in saline potentials (Figure 1D). Therefore, it was possible to identify statistical differences between the materials for each potential. At potentials of -0.1 and $-0.3 \mathrm{MPa}$, hybrid AP6002 appeared statistically superior to all others and gathered higher quantities of reserves. At a saline potential of - $0.6 \mathrm{MPa}$, hybrids AP6002 and AP8203 were statistically equivalent in the seedling dry mass. The dry mass could not be quantified at the potential of - $0.9 \mathrm{MPa}$ due to the absence of normal seedlings. As the germination of the seeds was compromised by the saline potentials, there was possibly no effective redistribution of the nutrients in the endosperm. This compromised the estimation of the dry mass of the seedlings. 

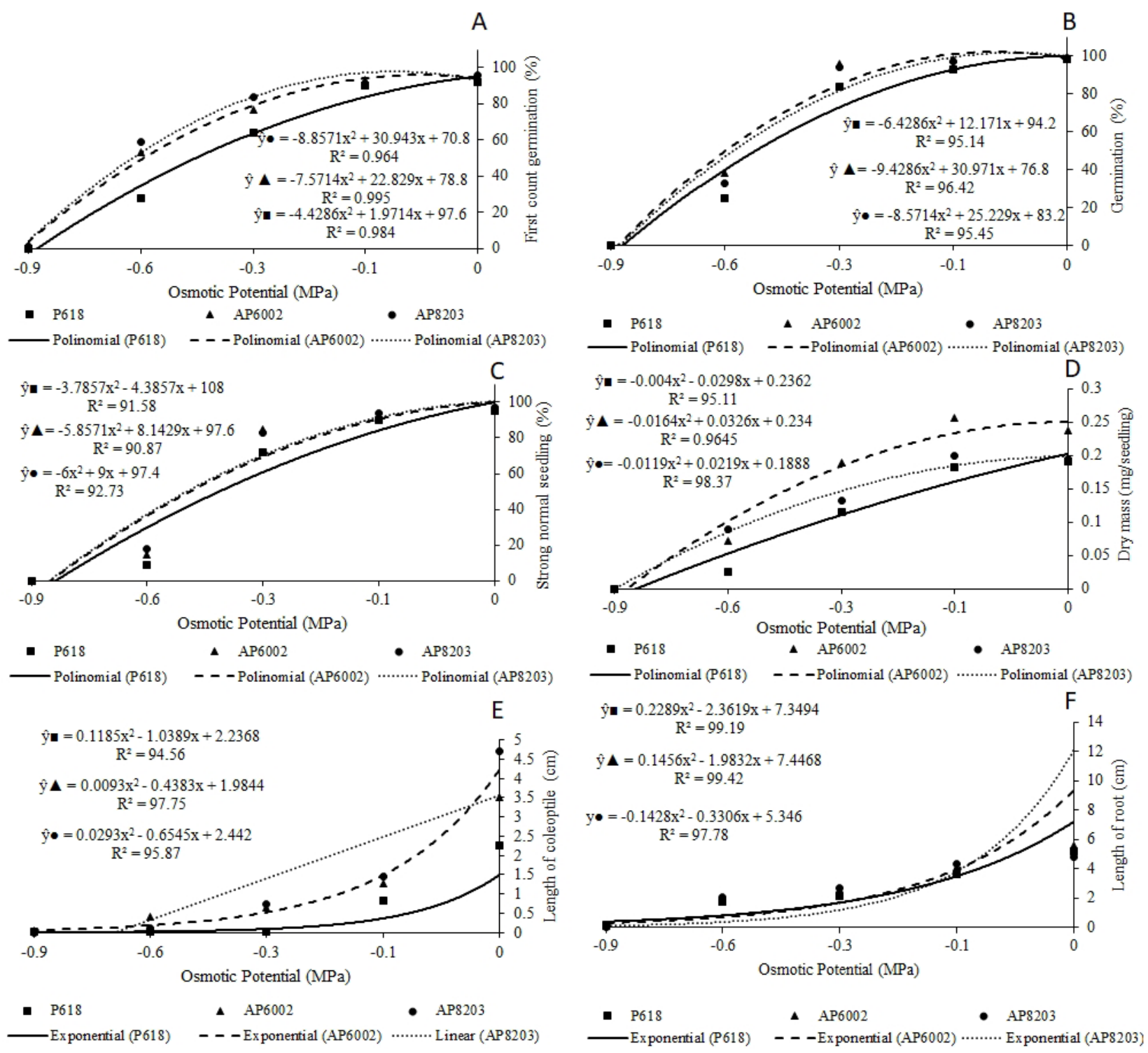

Figure 1: Protrusion (A), germination (B), strong normal seedlings (C), dry mass of seedlings (D), length of coleoptile $(E)$ and length of roots (F) from hybrids of popcorn under different osmotic potentials.

When corn seeds germinate in non-ideal conditions, the developed seedlings have a lesser capacity to tolerate stress (Silva-Neta et al., 2015). Thus, a strong selection pressure acts in response to germination, resulting in a series of strategies for the survival and establishment of seedlings (Spindelbock et al., 2013). It is important to emphasize that the initial growth of corn seedlings is usually related to seed vigor, and consequently, this may be reflected in the seedling performance (Mondo et al., 2013).
Computerized analysis using the Groundeye ${ }^{\circledR}$ software was efficient in assessing the vigor of the popcorn seedlings produced from seeds subjected to saline stress (Table 2). At a saline potential of - $0.6 \mathrm{MPa}$, hybrid AP6002 showed higher vigor of seedlings in terms of their coleoptile length (Figure 1E). However, no statistical difference was verified between hybrids when evaluating root length at the potential of $-0.6 \mathrm{MPa}$ (Figure 1F). 


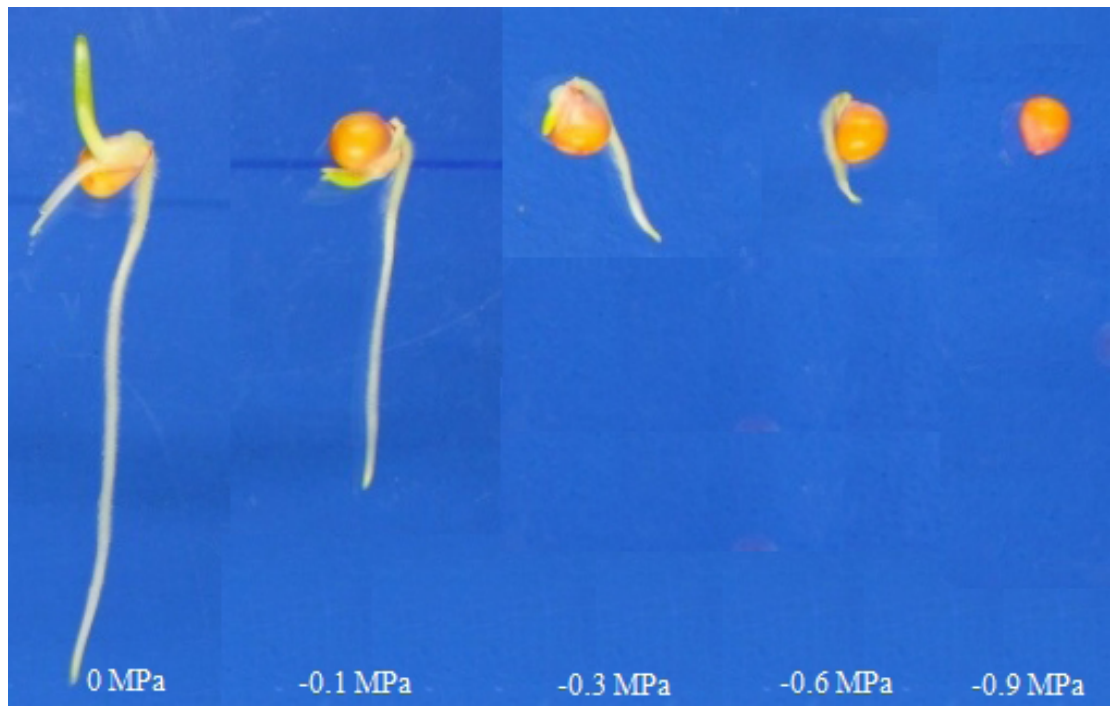

Figure 2: Development of popcorn seedlings AP6002 hybrid after saline stress in different osmotic potentials.

Table 2: Image analysis of popcorn seedlings using the software Groundeye ${ }^{\circledR}$, showing the values for the length of coleoptile (C), root length (R), index of growth, index of uniformity, and index of automatic vigor, in hybrid seeds under different osmotic potentials.

\begin{tabular}{ccccccc}
\hline Saline Potential & Hybrid & $\mathrm{C}(\mathrm{cm})$ & $\mathrm{R}(\mathrm{cm})$ & Growth & Uniformity & \multicolumn{1}{c}{ Vigor } \\
\hline \multirow{3}{*}{$0.0 \mathrm{MPa}$} & $\mathrm{P} 618$ & $2.248 \mathrm{C}$ & $5.208 \mathrm{~B}$ & $99.867 \mathrm{~A}$ & $85.131 \mathrm{~A}$ & $95.158 \mathrm{~A}$ \\
& AP6002 & $3.508 \mathrm{~B}$ & $5.611 \mathrm{~A}$ & $100.000 \mathrm{~A}$ & $83.459 \mathrm{~A}$ & $97.042 \mathrm{~A}$ \\
& AP8203 & $4.716 \mathrm{~A}$ & $4.840 \mathrm{~B}$ & $100.000 \mathrm{~A}$ & $84.684 \mathrm{~A}$ & $95.797 \mathrm{~A}$ \\
& P618 & $0.827 \mathrm{C}$ & $3.625 \mathrm{~B}$ & $38.444 \mathrm{~B}$ & $82.784 \mathrm{~A}$ & $41.749 \mathrm{~B}$ \\
$-0.1 \mathrm{MPa}$ & AP6002 & $1.278 \mathrm{~B}$ & $4.120 \mathrm{~A}$ & $44.501 \mathrm{~A}$ & $85.557 \mathrm{~A}$ & $55.846 \mathrm{~A}$ \\
& AP8203 & $1.454 \mathrm{~A}$ & $4.313 \mathrm{~A}$ & $46.764 \mathrm{~A}$ & $76.678 \mathrm{~A}$ & $58.818 \mathrm{~A}$ \\
& P618 & $0.015 \mathrm{~B}$ & $2.121 \mathrm{~B}$ & $21.254 \mathrm{~B}$ & $96.511 \mathrm{~A}$ & $33.831 \mathrm{~B}$ \\
$-0.3 \mathrm{MPa}$ & AP6002 & $0.638 \mathrm{~A}$ & $2.627 \mathrm{~A}$ & $28.258 \mathrm{~A}$ & $83.753 \mathrm{~A}$ & $44.941 \mathrm{~A}$ \\
& AP8203 & $0.735 \mathrm{~A}$ & $2.667 \mathrm{~A}$ & $28.079 \mathrm{~A}$ & $89.753 \mathrm{~A}$ & $45.831 \mathrm{~A}$ \\
& P618 & $0.012 \mathrm{~B}$ & $1.749 \mathrm{~A}$ & $11.527 \mathrm{~B}$ & $92.243 \mathrm{~A}$ & $28.942 \mathrm{~B}$ \\
$-0.6 \mathrm{MPa}$ & AP6002 & $0.400 \mathrm{~A}$ & $2.029 \mathrm{~A}$ & $20.857 \mathrm{~A}$ & $83.466 \mathrm{~A}$ & $39.640 \mathrm{~A}$ \\
& AP8203 & $0.098 \mathrm{~B}$ & $2.076 \mathrm{~A}$ & $20.928 \mathrm{~A}$ & $84.167 \mathrm{~A}$ & $36.900 \mathrm{~A}$ \\
& P618 & $0.016 \mathrm{~A}$ & $0.202 \mathrm{~A}$ & $10.062 \mathrm{~A}$ & $96.177 \mathrm{~A}$ & $26.425 \mathrm{~A}$ \\
$-0.9 \mathrm{MPa}$ & AP6002 & $0.034 \mathrm{~A}$ & $0.110 \mathrm{~A}$ & $11.288 \mathrm{~A}$ & $96.630 \mathrm{~A}$ & $26.899 \mathrm{~A}$ \\
& AP8203 & $0.000 \mathrm{~A}$ & $0.022 \mathrm{~A}$ & $12.026 \mathrm{~A}$ & $97.947 \mathrm{~A}$ & $27.271 \mathrm{~A}$ \\
CV (\%)= & & 11.85 & 18.65 & 5.54 & 5.09 & 4.13
\end{tabular}

Means followed by the same capital letter within the column are not statistically different by the Scott-Knott test at $5 \%$ probability.

It was possible to verify the statistical difference at the potential of $0.0 \mathrm{MPa}$ between the length of the coleoptile and the roots of the popcorn hybrids (Table 2).
The hybrid AP8203 displayed the longest length of the coleoptiles, while the hybrid AP6002 had the longest length of roots. Prazeres and Coelho (2016) state that these 
differences occur due to heterosis being influenced by the characteristics of their parents. In the evaluation of the hybrids, there were no differences in growth, uniformity, and vigor at $0.0 \mathrm{MPa}$.

Groundeye ${ }^{\circledR}$ was able to measure the minimum coleoptile and root growth of popcorn hybrids at a saline potential of $-0.9 \mathrm{MPa}$. However, no statistical differences were observed. It was not possible to visually detect the development of the vegetative seedling parts at this saline potential. The analysis of images with Groundeye ${ }^{\circledR}$ was efficient in evaluating the vigor of popcorn seeds under these conditions. Other authors have also verified the efficiency of this software under different experimental conditions. Catão and Caixeta (2017) evaluated the vigor of popcorn seeds under low germination temperatures and also stated that the software was effective in detecting differences in the physiological performance of the seeds.

Through the indices of growth, uniformity, and automatic vigor, the popcorn hybrids were classified within each saline potential evaluated (Table 1). All hybrids showed high vigor in the control treatment $(0.0$ $\mathrm{MPa}$ ) according to the evaluated indices. It was verified that as the saline potential increased, the vigor of hybrids diminished. Hybrid P618 showed the lowest growth and vigor indices at potentials of $-0.1 \mathrm{MPa},-0.3 \mathrm{MPa}$, and -0.6 $\mathrm{MPa}$. The use of image analysis allowed a safe assessment of the physiological potential of seeds (Silva; Cícero, 2014; Catão; Caixeta, 2017).

The parameters obtained from the computerized analysis of seedlings (seedling length and indices of vigor and growth of seedlings) are efficient to differentiate the vigor of seeds and seedlings of popcorn submitted to adverse conditions reliably. However, it is necessary that the seeds of the materials to be analyzed have high physiological potential to prevent the hybrid from influencing the results.

The parameters used in the analysis of images must be more precise than those used in the conventional assessment of physiological quality. This helps in presenting consistent responses to the classification of lots according to their performance (MarcosFilho, 2016). Thus, image analysis is considered a fast, accurate, simple, and economical method with replicable results and easy interpretation (Marcos-Filho, 2016). Environmental saline stress has been reported to jeopardize the physiological quality of seeds and reduce their viability in several reports.

Environmental stresses such as those caused by exposure to salinity damage the activity of the hydrolytic enzymes, increase the levels of lipid peroxidation and formation of ROS. Thereby, the synchronized action of the enzymes responsible for the removal of ROS confers higher tolerance to plants under stress conditions. Superoxide dismutase (SOD) is the first enzyme to act in the antioxidant system by performing the dismutation of superoxide radical $\left(\mathrm{O}_{2}^{-}\right)$to hydrogen peroxide $\left(\mathrm{H}_{2} \mathrm{O}_{2}\right)$. It showed slightly higher activity at all $\mathrm{KCl}$ potentials evaluated when compared to the control in hybrid P618. At saline potentials of $-0.6 \mathrm{MPa}$ and $-0.9 \mathrm{MPa}$, an increase in the SOD activity in hybrid AP6002 was observed when compared to the control treatment (Figure 3A); this typifies the detoxification of ROS. On the other hand, the activity of SOD in hybrid AP8203 slightly differed among all saline potentials evaluated.

The $\mathrm{H}_{2} \mathrm{O}_{2}$ generated by the activity of SOD is toxic and easily permeates the cellular membrane, thus requiring detoxification (Deuner et al., 2011). Thus, the action of enzymes such as ascorbate peroxidase (APX) and/or catalase (CAT) is essential.

Among the popcorn hybrids studied, a distinct behavior was observed in the activity of APX and CAT (Figure 3B and 3C). It was verified that the activity of APX decreased as the saline potentials were reduced. At a saline potential of $-0.9 \mathrm{MPa}$, hybrid $\mathrm{P} 618$ was an exception that showed a significant increment in the activity of APX when compared with the control. The APX activity in AP6002 and AP8203 hybrids was inferior to the control. This indicated a less efficient defense mechanism against oxidative stress under salt stress conditions.

The activity of CAT, in general, is inferior to that of APX due to its lower affinity for $\mathrm{H}_{2} \mathrm{O}_{2}$. Therefore, APX is more efficient in removing $\mathrm{H}_{2} \mathrm{O}_{2}$ (Deuner et al., 2011) Thus, a higher activity of CAT was observed in hybrid P618 at a saline potential of $-0.9 \mathrm{MPa}$. This was the hybrid with maximum expressed activity when compared with other hybrids. Possibly, this characteristic was intrinsic to this hybrid because the initial physiological quality of the seeds of the evaluated hybrids was excellent.

According to Laxa et al. (2019), the preservation of high activity levels of SOD, APX, and CAT is essential to maintain the equilibrium between the formation and exclusion of $\mathrm{H}_{2} \mathrm{O}_{2}$ from the intracellular environment in plants under conditions of environmental stress. Nevertheless, if a reduction in the CAT and APX activities and an increment in the peroxidase activity occurs, the generated $\mathrm{H}_{2} \mathrm{O}_{2}$ is preferably consumed in oxidative processes such as lipid peroxidation than being eliminated from the metabolism (Sharma et al., 2012). 
A

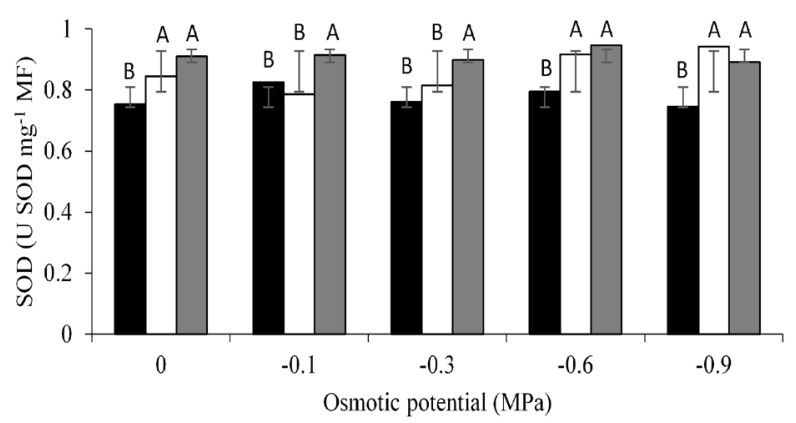

-P618 AP6002 口AP8203

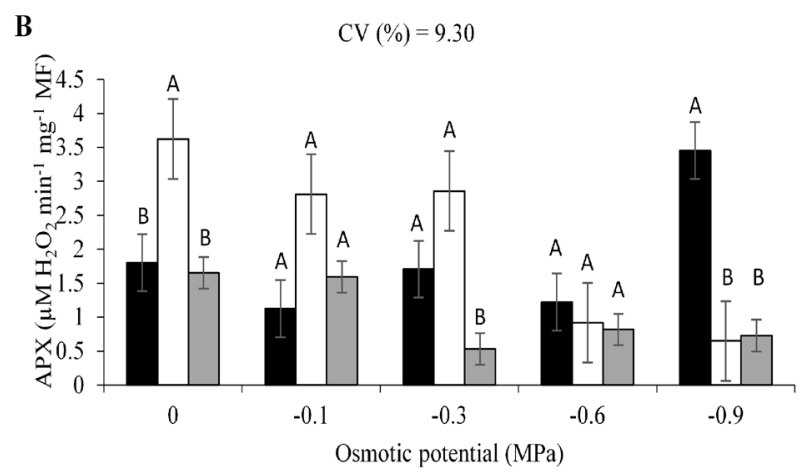

-P618 口AP6002 口AP8203

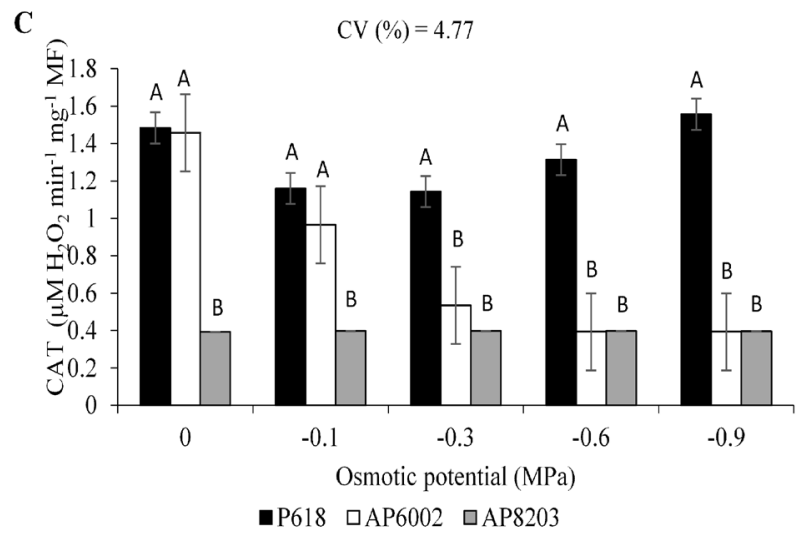

Figure 3: Specific activity of enzymes superoxide dismutase - SOD (A), ascorbate peroxidase - APX (B) and catalase - CAT (C) in the hybrids of popcorn under different osmotic potentials. * Means followed by the same letter are not statistically different by the ScottKnott test at 5\% probability.

A reduction in the activity of antioxidant enzymes SOD, APX, and CAT, along with higher peroxidation, was also verified in cowpea seedlings exposed to saline stress (Maia et al., 2012). In general and also because of the present results, it was possible to verify that a significant reduction occurred in the activity of the antioxidant enzymes under the saline potentials studied. This caused damage to the seeds due to oxidative processes formed by the exposure to $\mathrm{KCl}$. Moreover, it resulted in reduced germination and growth of popcorn seedlings at higher saline potentials.

\section{CONCLUSIONS}

Saline stress impairs the physiological quality and antioxidant activity of seeds and the performance of popcorn seedlings. Computerized image analysis using Groundeye $^{\circledR}$ was efficient for the evaluation of popcorn seedlings after the seeds were subjected to salt stress. AP6002 and AP8203 hybrids were more tolerant to salt stress than hybrid P618.

\section{REFERENCES}

ABREU, V. M. et al. Physiological performance and expression of isozymes in maize seeds subjected to water stress. Journal of Seed Science, 36(1):4047, 2014.

AZEVEDO, R. A. et al. Response of antioxidant enzymes to transfer from elevated carbon dioxide to air and ozone fumigation, in the leaves and roots of wild-type and a catalase-deficient mutant of barley. Physiology Plantarum, 104(2):280-292, 1998.

BEWLEY, J. D.; BLACK, M. Seeds: Physiology of development and germination. 2.ed. New York: Plenum Press, 1994. $445 p$.

BRASIL. Instrução Normativa $\mathbf{N}^{\circ} \mathbf{4 5}$, de 17 de Setembro de 2013. Diário Oficial da República Federativa do Brasil, Brasília, 23 dez. Seção 1, 2013. 22 p.

BRASIL. Ministério da Agricultura, Pecuária e Abastecimento. Regras para análise de sementes. Brasília: MAPA, 2009. 399p.

CATÃO, H. C. R. M.; CAIXETA, F. Physiological, isozyme changes and image analysis of popcorn seeds submitted to low temperatures. Journal of Seed Science, 39(3):234-243, 2017.

DEUNER, C. et al. Viabilidade e atividade antioxidante de sementes de genótipos de feijão-miúdo submetidos ao estresse salino. Revista Brasileira de Sementes, 33(4):711-720, 2011. 
EL-SHABRAWI, H. et al. Redox homeostasis, antioxidant defense, and methylglyoxal detoxification as markers for salt tolerance in Pokkali rice. Protoplasma, 245(1-4):8596, 2010.

FERREIRA, D. F. Sisvar: A computer statistical analysis system. Ciência e Agrotecnologia, 35(6):1039-1042, 2011.

FORMAN, H. J.; MAIORINO, M.; URSINI, F. Signaling functions of reactive oxygen species. Biochemistry, 49(5):835-842, 2010.

GIANNOPOLITIS, C. N.; RIES, S. K. Superoxide dismutases. Occurrence in higher plants. Plant Physiology, 59(2):309314, 1977.

JOSEPH, B.; JINI, D. Development of salt tress-tolerant plants by gene manipulation of antioxidant enzymes. Asian Journal of Agricultural Research, 5(1):17-27, 2011.

KAVAN, H. C. et al. Accelerated aging periods and its effects on electric conductivity of popcorn seeds. Revista de Ciências Agrárias, 42(1):40-48, 2019.

NAKAGAWA, J. Testes de vigor baseados no desempenho de plântulas. In: KRZYZANOWSKI, F. C.; VIEIRA, R. D.; FRANÇA NETO, J. B. Vigor de sementes: conceitos e testes. Londrina: ABRATES. 1999. 218p.

LAXA, M. et al. The role of the plant antioxidant system in drought tolerance. Antioxidants, 8(4):1-31, 2019.

MAIA, J. M. et al. Atividade de enzimas antioxidantes e inibição do crescimento radicular de feijão caupi sob diferentes níveis de salinidade. Acta Botanica Brasilica, 26(2):342349, 2012.

MARCOS-FILHO, J. Seed physiology of cultivated plants. Londrina: ABRATES, 2016. 616p.

MONDO, V. H. V. et al. Seed vigor and initial growth of corn crop. Journal of Seed Science, 35(1): 64-69, 2013.

MOTERLE, L. M. et al. Germinação de sementes e crescimento de plântulas de cultivares de milho-pipoca submetidas ao estresse hídrico e salino. Revista Brasileira de Sementes, 28(3):169-176, 2006.

NAKANO, Y.; ASADA, K. Hydrogen peroxide is scavenged by ascorbate specific peroxidase in spinach chloroplasts. Plant and Cell Physiology, 22(5):867-880, 1981.

PEREIRA, I. C.; CATÃO, H. C. R. M.; CAIXETA, F. Seed physiological quality and seedling growth of pea under water and salt stress. Revista Brasileira de Engenharia Agrícola e Ambiental, 24(2):95-100, 2020.

PEREIRA, M. R. R. et al. Estresse hídrico induzido por soluções de PEG e de $\mathrm{NaCl}$ na germinação de sementes de nabiça e fedegoso. Bioscience Journal, 30(3):687-696, 2014.

PINTO, C. A. G. et al. Image analysis in the evaluation of the physiological potential of maize seeds. Revista Ciência Agronômica, 46(2):319-328, 2015.

PRAZERES, C. S.; COELHO, C. M. M. Heterose para qualidade fisiológica de sementes na obtenção de híbridos de milho. Revista Brasileira de Milho e Sorgo, 15(1):124133, 2016.

ROCHA, C. S. et al. Physiological quality of popcorn seeds assessed by the accelerated aging test. Journal of Seed Science, 40(4):428-434, 2018.

SALISBURY, F. B.; ROSS, C. W. Plant physiology. 4.ed. Belmont: Wadsworth Publishing Company, 1991. 682p.

SHARMA, P. et al. Reactive oxygen species, oxidative damage, and antioxidative defense mechanism in plants under stressful conditions. Journal of Botany, 94:1-26, 2012.

SILVA, R. C.; GRZYBOWSKI, C. R. S.; PANOBIANCO, M. Vigor de sementes de milho: Influência no desenvolvimento de plântulas em condições de estresse salino. Revista Ciência Agronômica, 47(3):491-499, 2016.

SILVA, V. N.; CICERO, S. M. Avaliação do vigor de sementes de tomate durante o armazenamento por meio de análise computadorizada de imagens de plântulas. Semina: Ciências Agrárias, 35(4):2317-2326, 2014.

SILVA-NETA, I. C. et al. Expression of genes related to tolerance to low temperature for maize seed germination. Genetics and Molecular Research, 14(1):2674-2690, 2015.

SPINDELBOCK, J. P. et al. Conditional cold avoidance drives between-population variation in germination behaviour in Calluna vulgaris. Annals of Botany, 112(5):801-810, 2013.

SUDÉRIO, F. B. et al. O estresse salino retarda o desenvolvimento morfofisiológico e a ativação de galactosidases de parede celular em caules de Vigna unguiculata. Acta Botanica Brasilica, 25(1):17-24, 2011.

TRUJILLO, H. A.; GOMES-JUNIOR, F. G.; CICERO, S. M. Digital images of seedling for evaluating coffee seed vigor. Journal of Seed Science, 41(1):60-68, 2019. 